\title{
Dossiê PET 20 Anos
}

Comemorar é muito mais que uma celebração, uma reunião. É um buscar nas origens aquilo que nos faz visualizar os caminhos que, enfim, chegaram àquela comemoração. Estamos diante, então, de uma memória reflexiva. A palavra "comemorar", per se, nos dá essa informação: levar-nos a memorar todos os acontecimentos, no sentido de uma trajetória. Essas memórias ficam marcadas em fontes oficiais, atas de reunião, fotografias, lembranças de quem fez parte da trajetória e é assim que pretendemos, brevemente, contar a história das duas décadas do Programa de Educação Tutorial, do Departamento de História, da Universidade Federal do Paraná.

Já nos idos de 1991, um importante debate se levantou sobre a necessidade de criar mais ambientes condicionantes de pesquisa aos graduandos da UFPR. Nesta senda, o PET História foi criado em 1992. O objetivo naquele momento era instrumentar os alunos do curso de licenciatura e bacharelado para o exercício de atividades voltadas ao ensino, pesquisa e extensão, visando, à prática interdisciplinar, um preparo consistente de futuros professores, a atividade ampla de pesquisa e estudo - para além das previstas na estrutura regular do curso - e a possibilidade de estimular o debate constante sobre os diversos modos de se produzir 
Cadernos de Clio, Curitiba, n. ${ }^{\circ}$ 3, 2012

o conhecimento histórico. Inicialmente, o Programa era denominado Programa Especial de Treinamento. Já no seu primeiro ano de funcionamento, o Programa foi avaliado pela CAPES como Muito Bom.

O Programa estava previsto para ser desenvolvido inicialmente em quatro anos, podendo prorrogar-se, caso houvesse pertinência. $\mathrm{O}$ fortalecimento do grupo agregou uma vinculação ao Departamento de História, a qual ocorre até os dias atuais. Tendo o professor Doutor Euclides Marchi como primeiro Professor-Tutor na coordenação geral e as professoras Elvira Mari Kubo e Marcia Dalledone Siqueira como tutoras, os primeiros alunos bolsistas foram: Nádia Maria Guariza, Rita de Cassia da Silva, Ana Paula Peters e Cláudio Moreschi Freire. A intenção era integrar mais quatro alunos por ano, até completar o número de doze bolsistas. Assim ocorreu e a composição do grupo PET que, atualmente, permanece a mesma, com o número máximo de doze bolsistas e a participação de até seis voluntários. Naquela época, segundo o professor Euclides Marchi, as estruturas do Programa eram modestas:

"Quando o PET foi aprovado e iniciou suas atividades, a estrutura era bastante simples. Na época não havia grandes aparatos tecnológicos e físicos. Aos poucos foi se consolidando e o Departamento cedeu uma sala com mesas e cadeiras e um 
computador para os estudos dos bolsistas e para as reuniões com os tutores" 1

A pesquisa e as atividades, realizadas pelo primeiro grupo, estavam relacionadas à Teoria da História e em implicações teóricometodológicas na historiografia; os objetivos eram atender ao ensino e à metodologia de pesquisa em História. O primeiro autor privilegiado em debate foi o medievalista Georges Duby. Nesta ocasião, o grupo contou com a colaboração da Professora Vânia Leite Fróes, da Universidade Federal Fluminense, inclusive com participações em reuniões internas e palestras para a graduação. O professor Doutor Euclides Marchi manteve-se como coordenador geral até o início de 1995. Neste mesmo ano, a tutoria passou para o Professor Doutor Ronald Ramineli. ${ }^{2} \mathrm{O}$ grupo manteve suas atividades visando uma formação mais ampla e uma maior integração com todo o departamento.

Em 1997, a tutoria ficou ao encargo do Professor Doutor Luiz Carlos Ribeiro. A partir do referido ano, o grupo editou um boletim informativo mensal, divulgando as atividades do PET e notícias de interesse geral de todos os alunos do curso de História. ${ }^{3}$ Um dos principais objetivos das atividades do grupo, nesse

\footnotetext{
${ }^{1}$ Entrevista do professor Euclides Marchi

${ }^{2}$ Atualmente é professor do Departamento de História da Universidade Federal Fluminense - UFF.

${ }^{3}$ Esse boletim foi reeditado nesse ano de 2012 em edição comemorativa. Pretende-se a manutenção do informativo no próximo ano.
} 
momento, era estimular a criatividade individual com vistas a um interesse coletivo definido por um eixo temático. A integração dos bolsistas com a comunidade interna e externa visava o aprimoramento da formação global, para além das exigências curriculares. Ao fim e ao cabo, o petiano devia ser capaz de articular sua formação dentro e fora da Universidade. O Professor Doutor Marcos Napolitano ${ }^{4}$ assumiu a função de tutor em 1999, em conjunto com o Professor Luiz Carlos Ribeiro. Durante esse período, desenvolveu-se um Guia sobre o Museu do Expedicionário, voltado para os professores e alunos do Ensino Fundamental e Médio.

Em 2001, o Professor Doutor Carlos Alberto Medeiros Lima assumiu a tutoria do grupo, visando temas abrangentes da historiografia em diálogo com outras áreas das Ciências Humanas. Por meio de pesquisas de interesse coletivo, textos e temas eram debatidos em reuniões semanais. Boa parte dos resultados da pesquisa era apresentada em eventos científicos da UFPR.

A tutoria seguinte ficaria sob a responsabilidade da Professora Doutora Ana Paula Vosne Martins. Já no início do cargo, em 2004, a professora encontrou dificuldades, as quais foram assim avaliadas por Martins:

\footnotetext{
${ }^{4}$ Atualmente é professor do Departamento de História da Universidade de São Paulo - USP.
} 
"De maneira improvisada e sem ouvir os tutores e os estudantes, como de uma maneira geral tem sido a história deste programa. O problema maior me parece ser a ausência de uma política clara, com objetivos exequíveis e principalmente a estabilidade do PET, como acontece com os programas e bolsas de pós-graduação. A cada mudança nos cargos políticos do MEC uma "nova" ideia sobre o PET aparece, trazendo com ela instabilidade e desinformação. No tempo em que fui tutora não havia canais de comunicação abertos com a direção do Programa em Brasília e as informações na UFPR eram muito truncadas e parciais." ${ }^{, 5}$

Essa transição gerou alguns transtornos burocráticos, fruto, também, da mutação de órgãos responsáveis pela gerência dos grupos PET pelo país. A tutoria da professora Ana Paula ficou marcada por uma intensa produção acadêmica. Em 2008 foi lançado o manual $O$ Cinema na Sala de Aula: uma abordagem didática, visando auxiliar professores dos Ensinos Fundamental e Médio com abordagens audiovisuais no cotidiano escolar. Em 2010 foi lançado o primeiro volume da presente Revista, a Cadernos de Clio, destinada a publicação de graduandos e recém-graduados. Visivelmente, uma grande oportunidade de expansão do conhecimento gestado nas graduações pelo Brasil. Além disso, abriu oportunidade aos membros do PET História UFPR para conhecer melhor a editoria de uma revista científica, certamente um fortalecimento no crescimento acadêmico de seus realizadores.

\footnotetext{
${ }^{5}$ Entrevista da Professora Ana Paula.
} 
Também teve início no período o evento intitulado Diálogos do $P E T$, idéia que, compartilhada com tutores de outros grupos PET (Filosofia, Ciências Sociais e Direito), foi muito importante frente às concepções que então vigoravam sobre o programa na UFPR.

Em setembro de 2010 encerrou-se a tutoria da professora Ana Paula, a mais longa até então. A referida professora avaliou sua gestão enquanto satisfatória, sendo importante, também, em sua trajetória enquanto professora universitária. Desde então, a tutoria do PET História passou para a Professora Doutora Renata Senna Garraffoni como tutora do PET História.

As atividades desenvolvidas atualmente pelo grupo são resultados dos trabalhos realizados nos últimos vinte anos. Ao longo desse período, o PET desenvolveu diversas propostas que buscassem um conhecimento amplo, estabelecendo contatos entre alunos e professores. As pesquisas realizadas coletivamente por todos os grupos que passaram pelo PET muito acrescentaram na formação acadêmica dos participantes, assim como as pesquisas individuais, gerando possibilidades de ingressos nos programas de pós-graduação. As atividades de extensão e de ensino mantiveramse ao longo desse período, possibilitando uma maior amplitude nas relações acadêmicas e nas possibilidades de relacionamento e de uma maior experiência.

Para além da função intelectual, acadêmica, o PET História 
Cadernos de Clio, Curitiba, n. ${ }^{\text {o }}$ 3, 2012

preenche uma importante função social: prova disso está nos manuais produzidos visando retirar o conhecimento produzido na Universidade e distribuí-lo na comunidade estudantil geral. Não se trata de um grupo formador de uma elite intelectual, que visa o topo do conhecimento - como se assim houvesse uma disputa. Tampouco se trata de um antiacademicismo. Em sua essência, é formado por graduandos, em início de formação, visando as melhores maneiras para obter conhecimento e desenvolvimento intelectual.

PET-História

Novembro de 2012. 